\title{
Entrepreneurship and Innovation in China and Mexico: An Analysis from the Public Policies Perspective
}

\author{
Juan Carlos Tello Prior \\ Management Faculty, Benemérita Universidad Autónoma de Puebla, Puebla, Mexico \\ Email address: \\ carlos.tellop@correo.buap.mx \\ To cite this article: \\ Juan Carlos Tello Prior. Entrepreneurship and Innovation in China and Mexico: An Analysis from the Public Policies Perspective. Science \\ Journal of Business and Management. Vol. 5, No. 4, 2017, pp. 175-180. doi: 10.11648/j.sjbm.20170504.16
}

Received: June 30, 2017; Accepted: August 11, 2017; Published: August 22, 2017

\begin{abstract}
Entrepreneurship has been related to the accomplishment of macroeconomic goals in economic development, economic growth and international competitiveness between countries. Mexico has needed to cope with the new trends in business management under a perspective of advancement by the use of entrepreneurship and innovation as a way to achieve these requirements, this has generated the incipient need to stipulate public policies that contribute to an effective administration of these trends. However, despite of the efforts, the dynamics of adherence to innovation and development of technology-based companies still rests on limited indicators that have not contributed to the achievement of the macroeconomic objectives raised around the theme. On the other hand, China has been able to contextualize properly its private capital investment initiatives. The public policies are focused into stimulating and strengthening the emerging economic sectors, so they have been characterized by contributing to the research and development of new products and services. This, has generated an effective international positioning in virtue of the competitiveness of its sectors and economic growth attached to a propitious usage and application of both variables. The comparison of both realities allows an approach to the maneuvers that have been carried out in Mexico and China to glimpse opportunities and threats in the manipulation of these factors, that vary according to the specific environment and context of each one of these countries, in the face of the emergence of world markets which denote a closer link between government and industry in the achievement of sustainable and strengthened economic sectors.
\end{abstract}

Keywords: Entrepreneurship, Innovation, Mexico, China, Public Policies

\section{Introduction}

In the pursuit of competitiveness around the countries worldwide, the efforts have been concentrated in stimulating the avant-garde trends for the manipulation of the macroeconomic variables, with the intention of strengthening the domestic markets and to consolidate the actions in the face of the global commerce [1]. The entrepreneurship it's presented as an alternative that helps with this reality and stablishes the capacity of the nations to contribute to their objectives of socioeconomic growth and development, through the implementation of new trends of strategic management that provides the economic sectors with capabilities to be used by the private capital initiatives of inversion and a new gamma of valor proposals that are adjusted to the expectations of the market.

To achieve this goals, it's essential the existence of an adaption and linkage between the public policies promoted by the State to support these two variables (entrepreneurship and innovation), but at the same time, a proper management of them with the intention of generating encouraging indicators for the socials groups in the country and the macroeconomic goals followed [2]. Taking as an emphasis in this analysis the context followed by China and Mexico, nations that in terms of the Global Entrepreneurship Monitor, Global Entrepreneurship Index, the World Bank, the World Economic Forum and the Organization for Economic Cooperation and Development (OECD) are determined as efficiency-driven economies and must transit into innovation-driven economies as the international markets demand.

Taking back what Acs, et al. [2] propose, it is argued that in the world orb the entrepreneurship is identified as a socioeconomic trend that favors significantly the objectives of growth and economic development, by this conditions, the public policies have been oriented to increase and stimulate it 
among the population. However, it is presumed at the same time that the effectiveness of these policies in maximizing this current has been far from providing a favorable result, which will be analyzed from the view of the study nations in this writing.

For Ahlstrom \& Ding [3] entrepreneurship in China was an implausible reality in the last century, however, the objectives of economic growth and international positioning through an assimilation scheme of the globalization process, have allowed a more timely and detailed approach of the public management for this variable, evidence of this, is presented around the historical changes that were generated because of the public reforms that give greater importance to the liberation of foreign capital investment since 1978, and a gradual liberalization of the economy by means of the population efforts, that is strengthened in the early 90's, catapulting the economic sector represented by the MSME typology and the importance it has for the internal and external economy of this country.

In the case of Mexico, the context is similar, it is up to the commercial opening achieved in 1986 that was initiated a process of formulation of public policies aimed to the positioning and development of the internal industrial market [4], taking into account that the entrepreneurial motivation of the population and competitiveness of the MSME sector becomes a watershed as the internationalization of the country advances in the mid-1990s [5], this generates that entrepreneurship and innovation in economic sectors convert into important contemporary variables of management for Mexican territory and the public policies determined in it.

The work methodology focuses on a comparative analysis of the realities that have arisen between Mexico and China, in relation to the public policies of entrepreneurship and innovation and the management that the States consider with respect of them, the purpose of the study is to analyze in an exploratory way the public policies of entrepreneurship and its results in the field of innovation and development of new economic sectors between Mexico and China.

\section{Comparison: Mexico and China's Context in Entrepreneurship and Innovation}

For China's context, Yapeng \& Diguen [6] analyze the theoretical particularities of the public policies that create the bases for the entrepreneurship as a management trend and determine according to the principles of Heilmann, Qian and Roland, and Jin et al. cited in [6] that the main success of the State is based in a proper application of innovation policy, where governments have gained autonomy over the administration of Research and Development (R\&D) but at the same time the application of factors like investment, access to Information and Communication Technologies (ICT) that are linked to the national interests.

The arguments of the World Economic Forum [7] the entrepreneurial ecosystem can be understood as a business and market environment, in which administrative conditions and investment initiatives exist and look forward to promote and stimulate the creation and development of businesses, so, to understand this term, it is indispensable to go back to the arguments of Daniel Isenberg [8] who proposes nine pillars that give origin, sustenance and follow-up to the analysis of the entrepreneurial ecosystem; government policy, regulatory framework and infrastructure, funding, administrative culture, domestic and global markets, human capital and workforce, training and consulting, universities and academia, mentoring and support systems. All of them related with the purpose of guaranteeing a propitious and competitive ecosystem in the global context of work.

According to Schøtt \& Wickstrøm [8] there is an incessant need to make a connection between public policies and the business entrepreneurship strategies followed by the countries, determining that those with a more advanced development have succeeded to create this correlation of variables and achieving significant results and goals, meanwhile, those in emergency, require to manipulate appropriately these factors in the consecution of the accomplishments they presuppose.

These premises are related to the precepts of competitiveness specified by the World Economic Forum [9], China's migration from an efficiency driven economy to an innovation driven economy is on the way, while the case of Mexico is considered away to take into account this capacity for change. In Storey [10], it is argued that the nations that have coped better with the entrepreneurial variable have been able to accurately handle public and private investment in relation to innovation which demarcates their capacity to achieve the development and economic growth objectives proposed by entrepreneurship. To put it in context, it is cited Van Praag and Versloot [10] who define four basic benefits to the macroeconomic objectives of a nation thanks to entrepreneurship, in this case they are job creation, innovation, productivity and growth, which increases the internal profits of the population, their satisfaction and distribution of wealth.

The historical analysis show that the conditions of commercial opening towards private investment has paths that date from differentiated years around the evolutionary behavior of this situation for the cases of Mexico and China, in the first case these characteristics are concentrated in line with the internationalization and commercial opening (1986 to 1995), while China's handling of these factors takes a few years of advance with its Latin American counterpart through a period of manipulation that goes from 1978 to 1992 with the reforms and liberalization of the economy.

In terms of Story [11] Mexico has suffered from an orientation of its economic and business units in the services sector, followed by the industrial sector, the latter, being the one in which the greatest opportunities for technological development and innovation are displayed, which has stalled the country in the face of these inferences and variables.

Part of the problems of entrepreneurship in Mexico it's associated with the regulation and normative, that have 
turned theirself complex and inefficient for an appropriate regulation of the private capital entrepreneurial initiatives, that have been directed to a change in the entrepreneurship patterns but, at the same time, have awakened the intention of the entrepreneurial sectors to adhere to informality, related to the constant adaptations of the normative, taxable base and domestic policy [12].

Federal initiatives and regulations proclaimed the need to stimulate innovation and development of new economic sectors since year 2010, currently these tasks and activities have been redesigned and reformulated in an institutional way, to be manipulated through a public work system opened to the population and primarily managed by the National Institute for Entrepreneurship, the Ministry of Economy and the National Council of Science and Technology (INADEM, SE and CONACYT by their acronym in Spanish correspondingly).

In order to achieve a favorable vision of the public management of policies to stimulate entrepreneurship and innovation, the State Council in China has determined, from the year 2016, the scenario of achievements to be accomplished to make structural reforms in the internal administrative environment, with the purpose of strengthening the economic sectors, to mitigate weaknesses in the current economic system and to turn the nation from an efficiency driven economy to one that allocates it's public strategies to innovation driven stage, this by the massification and intensification of the entrepreneurship and innovation public policies [13].

With these decisions, the State warns as a priority its intentions to improve the institutional mechanisms to facilitate the consecution of the objectives to develop these administration currents, as well as the creation of an entrepreneurial ecosystem with a fair and competitive market and internal reform systems that contribute to an enhancement of intellectual property, as well as a more assiduous support in relation to funding and investment in the development of these trends and interconnectivity with the sectors of internal and external financing (public and private banking) that guarantee the investment decisions of Chinese entrepreneurs looking for innovation base firms creation are supported by different funding alternatives.

Private initiatives in China have grown despite having a rigid normative system and mechanisms of work for the legal and financial terms [14] but at the same time, in the macroeconomic environment, the State has consolidated ecosystems of entrepreneurship that have weakened the shortcomings of the new generation of entrepreneurs and an emergency of this variable in response to the aims of positioning and solidification of the domestic market, currently succeeding in solidifying institutions and taking a more successful control of the nation's entrepreneurial activities [3].

In terms of the indicators generated by the global studies of entrepreneurship and innovation (Such as GEDI or GEM) the results are diversified for the case of Mexico and China, according to the comparative factors presented in chart 1 , it can be analyzed how Mexico is well below the results achieved by China, however, it is also to be pointed that the economic emergency and the socio demo figure context are very distant between one country and the other.

The reality in the implementation of public policies by each country can be denoted in a more specific way evaluating the international results that have been generated as reported to different reports and indicators presented by supranational institutions and multilateral forums, for this, can be verified how China has reflected a more appropriate management in the contemporary vision of its public policies by giving favorable results in terms of innovation and development of the economic sectors, being far above the Mexican reality in the skill and success for the management of them (see table 1). This leads us to think about the need for a comprehensive diagnosis of the structure of public policies to stimulate and promote this variable in Mexico, in order to identify areas of opportunity and more assertive strategic planning when propelling innovation as a result of entrepreneurship and business development by the State by its public policies.

Table 1. Comparative indicators in entrepreneurship and innovation by Mexico and China (2013-2016).

\begin{tabular}{|c|c|c|}
\hline Indicator & México & China \\
\hline Innovation World Rank (GII, 2016) & 61 place & 25 place \\
\hline Innovation Quality (GII, 2015) & 36 place & 18 place \\
\hline GDP investment in R\&D (WB, 2015) & $0.5 \%$ of GDP & $2 \%$ of GDP \\
\hline R\&D ranking (GII, 2016) & 41 place & 18 place \\
\hline Triadic patents (WB, 2015) & 19 families & 1896 families. \\
\hline Political environment for innovation (GII, 2016) & 65 place & 79 place \\
\hline Available infrastructure for innovation (GII, 2016) & 67 place & 36 place \\
\hline Business sophistication (GII, 2016) & 77 place & 7 place \\
\hline Technology and acknowledgment development (GII, 2016) & 70 place & 6 place \\
\hline Creativity for innovation (GII, 2016) & 62 place & 30 place \\
\hline Global entrepreneurship rank (GEDI, 2016) & 71 place & 46 place \\
\hline Opportunities perceived (GEDI, 2016) & $48 \%$ & $13 . \%$ \\
\hline
\end{tabular}




\begin{tabular}{lll}
\hline Indicator & México & China \\
\hline Capabilities perceived (GEM, 2014) & $33 \%$ & $53.5 \%$ \\
Innovation in processes (GEDI, 2016) & $22 \%$ & $66 \%$ \\
Innovation in products (GEDI, 2016) & $26.3 \%$ & $83.3 \%$ \\
Risk acceptance (GEDI, 2016) & $40 \%$ & $52 \%$ \\
Competitiveness perceived (GEDI, 2016) & $26 \%$ & $25 \%$ \\
Funding (GEM, 2013) & 18 place & 3 place \\
Competitiveness perceived (GEDI, 2016) & $26 \%$ & $25 \%$ \\
Funding (GEM, 2013) & 18 place & 3 place \\
Competitiveness perceived (GEDI, 2016) & $26 \%$ & $25 \%$ \\
\hline
\end{tabular}

Source: Elaboration with data from the Global Entrepreneurship Monitor (2013, 2014, 2015), Global Entrepreneurship and Development Institute (2016), Global Innovation Index (2016), World Bank (2015).

To complement the analysis given by the indicators determined in table 1 , the indicators in R\&D investment, ICT goods and services manufacturing and exporting and the evolution of triadic patents are examined in the corresponding figures where it can be identified that China has a clearly superiority to Mexico in the innovation indicators since the mid-90's, derived from the State's effective design and implementation of public policies to encourage this area.

Figure 1, shows the percentage assigned to R\&D investment and it can be seen that for Mexico it represents only $0.5 \%$ of the GDP economy flow of domestic and international activities, however, China invests more than $2 \%$ of their total economy workflows fact that has stimulated in a more proper way the innovation results presented as indicators previously.

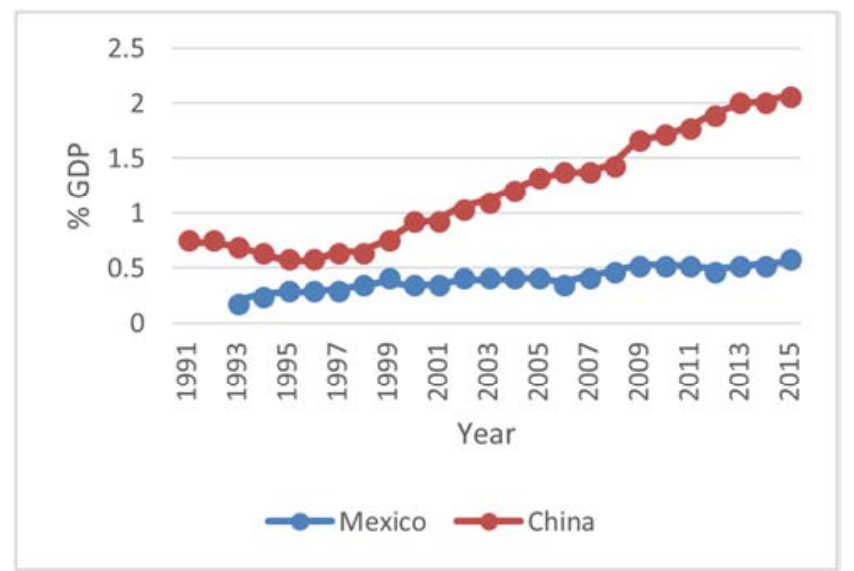

Source: Elaboration with OECD data (2016)

Figure 1. Percentage of GDP invested in R\&D: Mexico-China (1991-2015).

Figure 2 presents the R\&D expense and investment made by Mexico and China's government in terms of the GDP since 1991 to 2015, where it can be detected that the difference it's very wide between both countries, China has a better economy workflow that lets investing over 376858.9221 million of USD dollar, while Mexico only invests 10987.93. This context allows to comprehend the importance of changing public policy design for this nation and the need to increment its public expenses in science and technology (see figure 2).

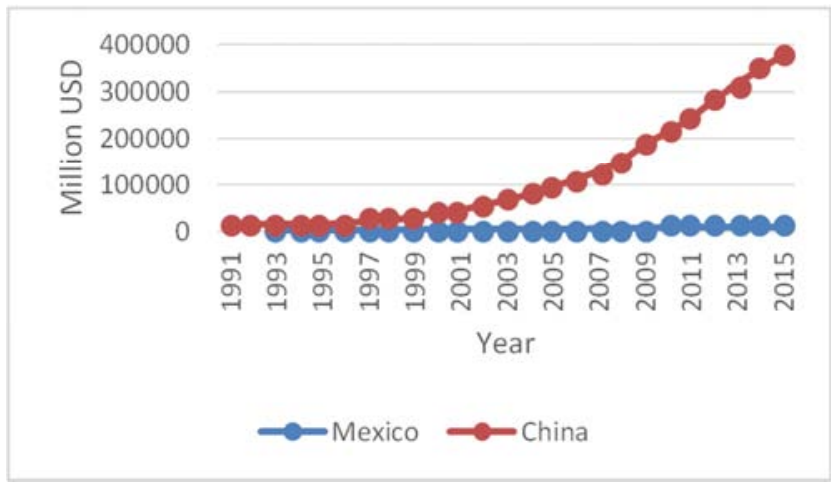

Source: Elaboration with OECD data (2016)

Figure 2. GDP invested in R\&D Million USD: Mexico-China (1991-2015).

Triadic patents it's a concept proposed by the World Bank referred to a set of patents registered in various countries) to protect the same invention [15] in Mexico by the year 2015 there were only 17.74 families with intellectual property patented, meanwhile, China registered 2582.30, the indicator reflects an enormous discrepancy between this nations, facts that bring near China to migrate to an innovation driven economy and privates Mexico to advance with significant advances in this objective (see figure 3 ).

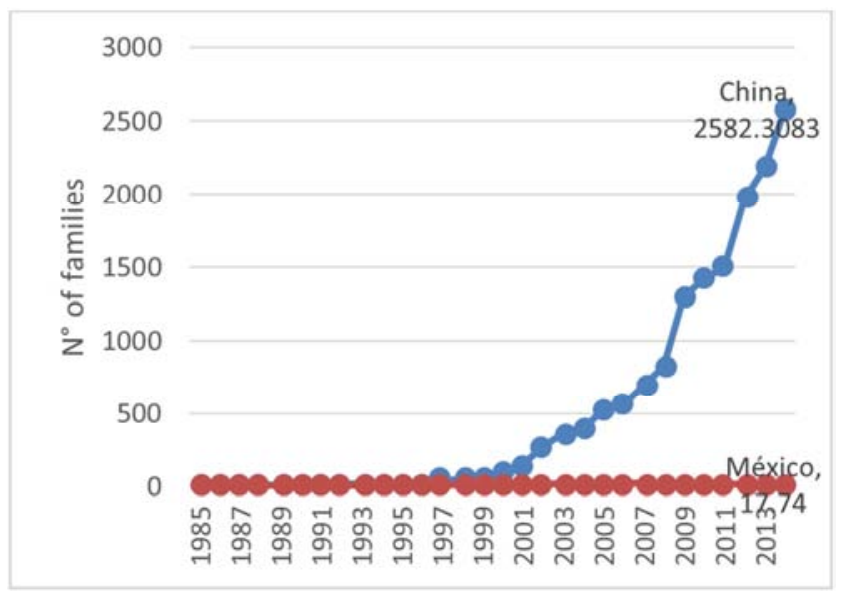

Source: Elaboration with OECD data (2016)

Figure 3. Triadic patents Mexico-China (1985-2014). 
From the year 2000, China has taken the lead in the exportation of ICT goods and services, Mexico has lower indicators in this area in terms of the percentage of GDP that the technology and applied science generate for the economy workflow, whereas China attains more than 10 percentile points over Mexico, this determines the absence of effective goals to potentiate the country with new economic sectors provided by entrepreneurship initiatives (see figure 4).

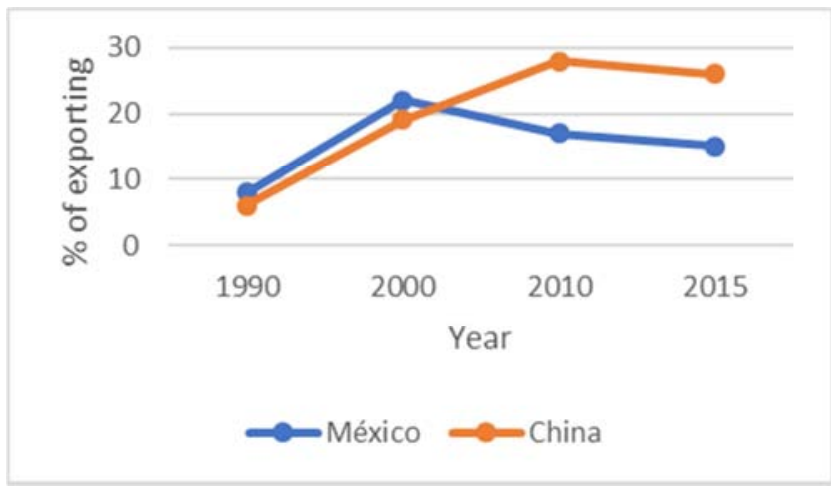

Source: Elaboration with World Bank data (2016)

Figure 4. High Technology exports: Mexico-China (1990-2015, \% of manufactured exports).

Finally, the analysis presents the ICT exportations of good and services from China and Mexico by the amount of GDP contributed to macroeconomic indicators for both countries, China ascends to 550,000 million of USD and Mexico remains in the limit of the 100,000 million of USD (see figure 5). The whole evaluation of the indicators and figures permits to argue that China's manipulation of innovation public policy has got better results than Mexico, but, Mexico's government has been acting to redesign the policy in order to enhance its innovation conditions.

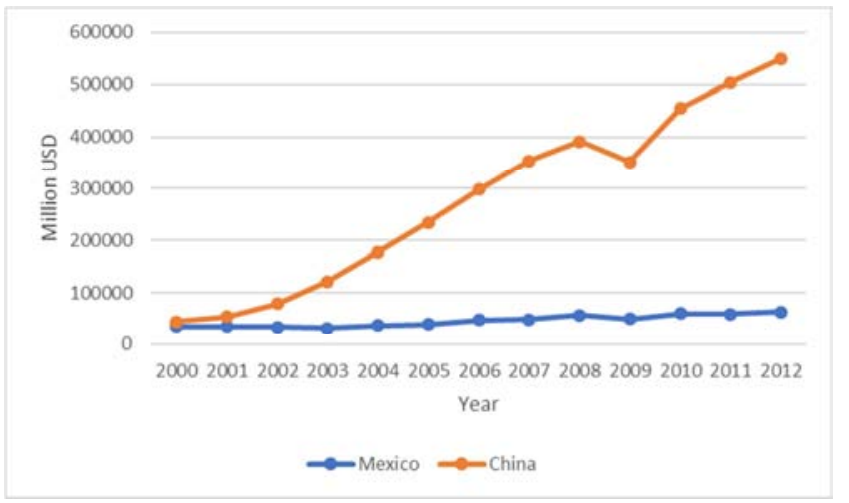

Source: Elaboration with World Bank data (2016)

Figure 5. Percentage of GDP invested in R\&D: Mexico-China (1991-2015).

Conforming to the comparative analysis it can be glimpsed how China's government connects the public policies and economy decisions in the attach of entrepreneurship and innovation, which has contributed significantly in the good results for both variables, thanks to the control provided by the government and it's close relation with institutions. On the other hand, Mexico has taken root within the design of the public policy to attend the economic development goals, failing to consolidate more demonstrative achievements in the field of innovation and international positioning.

\section{Conclusions}

The results analyzed, determine that the path and reality reached in relation to entrepreneurship between the two countries is in line with their capacity for the formulation, design and control of their public policies to stimulate and supervise each constant examined. For China, the adaptation of its policy has allowed a more specific control of the State, which has also provided stability in order to ensure the success and good traceability of the results accomplished, as well as greater coercibility and action field to manage the strategic plans and projects of private enterprises and emerging firms.

Meanwhile, Mexico has turned its decisions of public policy for entrepreneurship and innovation in the resolution of socioeconomic problems and the assurance of economic development goals, which has resulted in an inappropriate promotion of innovation by concentrating investments and public funding in traditional economical sectoral schemes that are far from the objectives of technological development and creation of technology-based companies. So, the readjustments of public policy proposed by National Institute for entrepreneurship (INADEM, 2017) are visualized with a re-engineering of global strategies that satisfy the national expectative regarding the innovation factors.

It is worth highlighting what Tse (2016) mentions, who reports that China's conception of innovation and development of private investment initiatives is in an evolutionary process, taking into account that it has been growing only for a couple of decades, in Mexico, economic liberalization in similar temporal scenarios has been reduced by a non-exponential advance in the indicators reflected. Wood (2014) determines a hostile scenario in the management of entrepreneurship and innovation as its result, but at the same time a learning cycle based on the strategies implemented by the developed economies, enabling them to respond proactively and intelligently to the challenges of globalization and internationalization of economic sectors in the face of competitiveness.

\section{References}

[1] C. Marquis y M. R., «Institutional Strategies in Emerging Markets», Harvard Business School, Cambridge, 2014.

[2] Z. Acs, T. Astrebro, D. Audretsch y R. David, «Public policy to promote entrepreneurship: a call to arms», Small Business Economic, no 47, pp. 35-51, 2016.

[3] D. Ahlstrom y Z. Ding, «Entrepreneurship in China: An overview», International Small Business Journal, vol. 32, nº 6 , pp. 610-618, September 2014. 
[4] G. Hanson, «Understanding Mexico's Economic Underperformance», Migration Policy Institute, Washington, 2011.

[5] R. Crandall, G. Paz y R. Roett, Mexico's Democracy at Work: Political and Economic Dynamics, Boulder: Lynne Rienner, 2005.

[6] Y. Z. D. Xiao, «Policy entrepreneur and social policy innovation in China», The Journal of Chinese Sociology, vol. 02, nº 10, pp. 1-17, 2015.

[7] World Economic Forum, «World Economic Forum», 2016 [En línea]. Available:

http://reports.weforum.org/global-competitiveness-report-201 5-2016/competitiveness-rankings/.

[8] D. Isenberg, «Entrepreneurial Ecosystems Around the Globe and Early-Stage Company Growth Dynamics», World Economic Forum, Switzerland, 2010.

[9] T. Schøtt y K. Wickstrøm, «The Coupling between Entrepreneurship and Public Policy: Tight in Developed Countries but Loose in Developing Countries», Estudios de Economía, vol. 35, nº 2, pp. 195-214, Diciembre 2008.

[10] D. Storey, «Entrepreneurship and SME Policy», WORLD ENTREPRENEURSHIP FORUM, Warwick, 2008.

[11] D. Story, Industry, the State, and Public Policy in Mexico, Texas: University of Texas Press, 2014.

[12] OCDE, «OECD Perspectives: Mexico Key Policies for Sustainable Development», OCDE Publishing, Paris, 2010.
[13] The People's Republic of China State Council, «The State Council», 16 Junio 2016. [En línea]. Available: http://english.gov.cn/policies/latest releases/2015/06/16/conte nt_281475128473681.htm.

[14] Z. Chen y A. Newman, «Entrepreneurs, organizational members, political participation and preferential treatment: Evidence from China.», International Small Business Journal, vol. $30, n^{\circ} 8$, pp. 873-889., 2012.

[15] World Bank, «World Bank», 2017. [En línea]. Available: http://data.worldbank.org/.

[16] T. Mazzarol, 6 ways governments can encourage entrepreneurship, World Economic Forum, 2014.

[17] D. Audretsch, «Sustaining Innovation and Growth: Public Policy Support for Entrepreneurship», Industry and innovation, vol. 11, n 3, pp. 167-191, 2004.

[18] GEDI, «Global Entrepreneurship Development Index», GEDI, USA, 2016

[19] Global Entrepreneurship Monitor, «Reporte Nacional 2014 México», GEM, México, 2015.

[20] S. Dutta, B. Lanvin y S. Wunsch, «Global Innovation Index 2015: Effective Innovation Policies for Development», GII, Geneva, 2016.

[21] Instituto Nacional del Emprendedor, «INADEM», Abril 2017. [En línea]. Available: www.inadem.gob.mx/tutoriales. 